\title{
Classification of patients with breast cancer according to Nottingham Prognostic Index highlights significant differences in immunohistochemical marker expression
}

\author{
Fisnik Kurshumliu ${ }^{1,4^{*}}$, Lumturije Gashi-Luci ${ }^{1}$, Shahin Kadare ${ }^{2}$, Mehdi Alimehmeti ${ }^{3}$ and Ugur Gozalan ${ }^{4}$
}

\begin{abstract}
Background: Prognosis and treatment of patients with breast carcinoma of no special type (NST) is dependent on a few established parameters, such as tumor size, histological grade, lymph node stage, expression of estrogen receptor, progesterone receptor, and HER-2/neu, and proliferation index. The original Nottingham Prognostic Index (NPI) employs a three-tiered classification system that stratifies patients with breast cancer into good, moderate, and poor prognostic groups. The aim of our study was to use robust immunohistochemical methodology for determination of ER, PR, HER-2/neu, Ki-67, p53, and BCl-2, and to observe differences in the expression of these markers when patients are stratified according to the original, three-tiered Nottingham Prognostic Index.
\end{abstract}

Methods: Paraffin blocks from 120 patients diagnosed with breast carcinoma, NST, were retrieved from our archive. Cases included in the study were female patients previously treated with modified radical mastectomy and axillary dissection.

Results: Our study demonstrates that expression of markers of good prognosis, such as ER, $\mathrm{PR}$, and $\mathrm{BCl}-2$, is seen with higher frequency in good and moderate NPI groups. In contrast, overexpression of HER-2/neu, a marker of adverse prognosis, is more frequent in moderate and poor NPI groups. High proliferation index, as measured by Ki-67, is seen in moderate and poor NPI groups, whereas low proliferation index is seen in good NPI groups.

Conclusions: These data confirm that the original, three-tiered NPI statistically correlates with the expression of prognostic immunohistochemical markers in breast carcinoma NST.

Keywords: Breast cancer, Nottingham Prognostic Index, Immunohistochemistry

\section{Background}

The prognosis and treatment of patients with breast carcinoma of no special type (NST) are dependent on a few established parameters, such as tumor size, histological grade, lymph node stage, expression of estrogen receptor (ER), progesterone receptor (PR), overexpression of human epidermal growth factor receptor 2 HER-2), and proliferation index determined by Ki-67 [1-5].

\footnotetext{
* Correspondence: fkurshumliu@gmail.com

'Institute of Anatomic Pathology, University Clinical Center, Medical School, University of Pristina, Pristina, Kosovo

${ }^{4}$ American Hospital Kosova, Pristina, Kosovo

Full list of author information is available at the end of the article
}

Incorporation of genetic information, as determined by gene expression profiling (GEP) [6-8], is becoming a standard of care for patients with breast cancer [9-14]. However, this methodology is mainly restricted to selected institutions and issubject to issues related to sample processing, data interpretation, reproducibility, validation, feasibility, and cost [2]. These are of critical relevance in considering the need to identify the molecular features of individual tumors in routine practice [2].

The Nottingham Prognostic Index Plus (NPI+) evaluates the expression of ten protein biomarkers by immunohistochemistry in order to stratify patients into seven core classes: class 1 (Luminal A), class 2 (Luminal N), class 3 (Luminal B), class 4 (Basal, p53 
altered), class 5 (Basal, p53 normal), class 6 (HER-2/neu positive, ER positive), and class 7 (HER-2/neu positive, ER negative) $[1,2]$. These classes are comparable to those identified by GEP $[1,2]$.

The origins of this system date from a study in 1992, according to which the Nottingham Prognostic Index (NPI) is a numerical value that is calculated by adding the values of tumor diameter (multiplied by a coefficient of 0.2 ), histological grade (1 to 3 ), and lymph node stage (1 to 3 ) [15]. The original NPI employed a three-tiered classification system distinguishing good, moderate, and poor prognostic groups with cut-off points between the values $\leq 3.4,3.4$ to 5.4 , and $>5.4$ [15]. Over the years, this system has been modified to a four-to-six-tiered stratification with slight variability in interpretation $[2,16,17]$.

The aim of our study was to use robust immunohistochemical methodology for determination of ER, PRHER-2/ neu, Ki-67, p53, and Bcl-2, and to observe differences in expression of these markers when patients are stratified according to the original, three-tiered, N PI.

\section{Methods}

Paraffin blocks from 120 female patients diagnosed with breast carcinoma, NST, were retrieved from our archive. Patients had been treated with modified radical mastectomy and axillary dissection, and staged according to the pathologic tumor-node-metastasis (pTNM) system. Histological grade was determined through the Nottingham grading system, and the NPI was calculated accordingly (Table 1). Cases subjected to neoadjuvant therapy and with multifocal and/or multicentric foci were excluded from the study. Biopsy samples had been fixed in $10 \%$ neutral buffered formalin and sectioned in 3- 4micron sections. All biopsy samples were previously evaluated by two independent pathologists. The study is conducted in compliance with the principles of Declaration of Helsinki and approved by the Ethical and Professional Committee.

\section{Immunohistochemistry}

Antigens were retrieved by placing the slides in target retrieval solution for $45 \mathrm{~min}$ at $9598^{\circ} \mathrm{C}$ (Table 2). The slides were incubated with the primary antibody for $30 \mathrm{~min}$. The visualization was carried out with dextran

Table 1 The original Nottingham Prognostic Index

\begin{tabular}{cc}
\hline \multicolumn{2}{c}{ NPI $^{*}$} \\
\hline Value & Prognosis \\
\hline$\leq 3.4$ & Good \\
3.415 .4 & Moderate \\
$>5.4$ & Poor \\
\hline
\end{tabular}

${ }^{*} \mathrm{NPI}=$ tumor size in $\mathrm{cm} \times 0.2+$ histological grade [1- 3] + number of positive lymph nodes [ $1=0$ nodes; $2=13$ nodes; $3>3$ nodes].
Table 2 Antibodies, vendor, pretreatment, and dilution

\begin{tabular}{ccccc}
\hline Antibody & Clone & Source & Pretreatment & Dilution \\
\hline ER & 1D5 & DAKO & $\mathrm{pH} \mathrm{9.0}$ & $1: 35$ \\
PR & 636 & DAKO & $\mathrm{pH} \mathrm{9.0}$ & $1: 50$ \\
HER-2 & HercepTest & DAKO & $\mathrm{pH} 6.1$ & Ready to use \\
Ki-67 & MIB-1 & DAKO & $\mathrm{pH} \mathrm{9.0}$ & $1: 100$ \\
p53 & DO-7 & DAKO & $\mathrm{pH} \mathrm{9.0}$ & $1: 1000$ \\
Bcl-2 & 124 & DAKO & $\mathrm{pH} \mathrm{9.0}$ & $1: 100$ \\
\hline
\end{tabular}

polymer conjugated with peroxidase and secondary antibody (EnVision+, DAKO, Denmark, K534011) for $30 \mathrm{~min}$.

\section{Interpretation of results}

The interpretation of ER, PR, and HER-2/neu immunohistochemistry was carried out according to American Society of Clinical Oncology (ASCO) guidelines $[18,19]$. A positive result for ER and PR was any nuclear stain observed in more than $1 \%$ of the tumor cells [18]. Non-neoplastic epithelium of the normal terminal duct-lobular unit was used as an internal control. The staining pattern for HER-2/neu was scored on a scale of 0 to $3+$. Negative for HER-2/neu overexpression were scores 0 and $1+$. Positive results were membranous staining with a score of 3+ [19]. Cases with "equivocal" results $(2+)$ were excluded in order to restrict to immunohistochemical methodology.

The interpretation of proliferative index as measured by $\mathrm{Ki}-67$ was carried out by estimating the percentage of cells with nuclear stain in the most mitotically active areas. The cut-off point between low and high proliferative index was $14 \%$, according to St. Gallen criteria [20].

Cytoplasmic staining with $\mathrm{Bcl}-2$ was interpreted by using a cut-off value of $10 \%$ between negative and positive results [21].

The interpretation of p53 was carried out by estimating the proportion of tumor cells with nuclear stain. A positive result was any value above 10\% [22].

The data were statistically analyzed with the chi-square and Kruskal-Wallis methods.

\section{Results}

Paraffin blocks from 120 female patients diagnosed with breast carcinoma, NST, were analyzed. Positive expression of ER and PR was inversely related to the NPI numerical value. This difference was statistically significant between the NPI groups $P<0.01$ ); see Figure 1 and Table 3.

Overexpression of HER-2/neu was in direct correlation with NPI numerical value. This difference was statistically significant between the NPI groups $(P=0.01)$; see Figure 1 and Table 3. Similarly, high proliferation index, as measured by Ki-67, was more frequent with increasing 

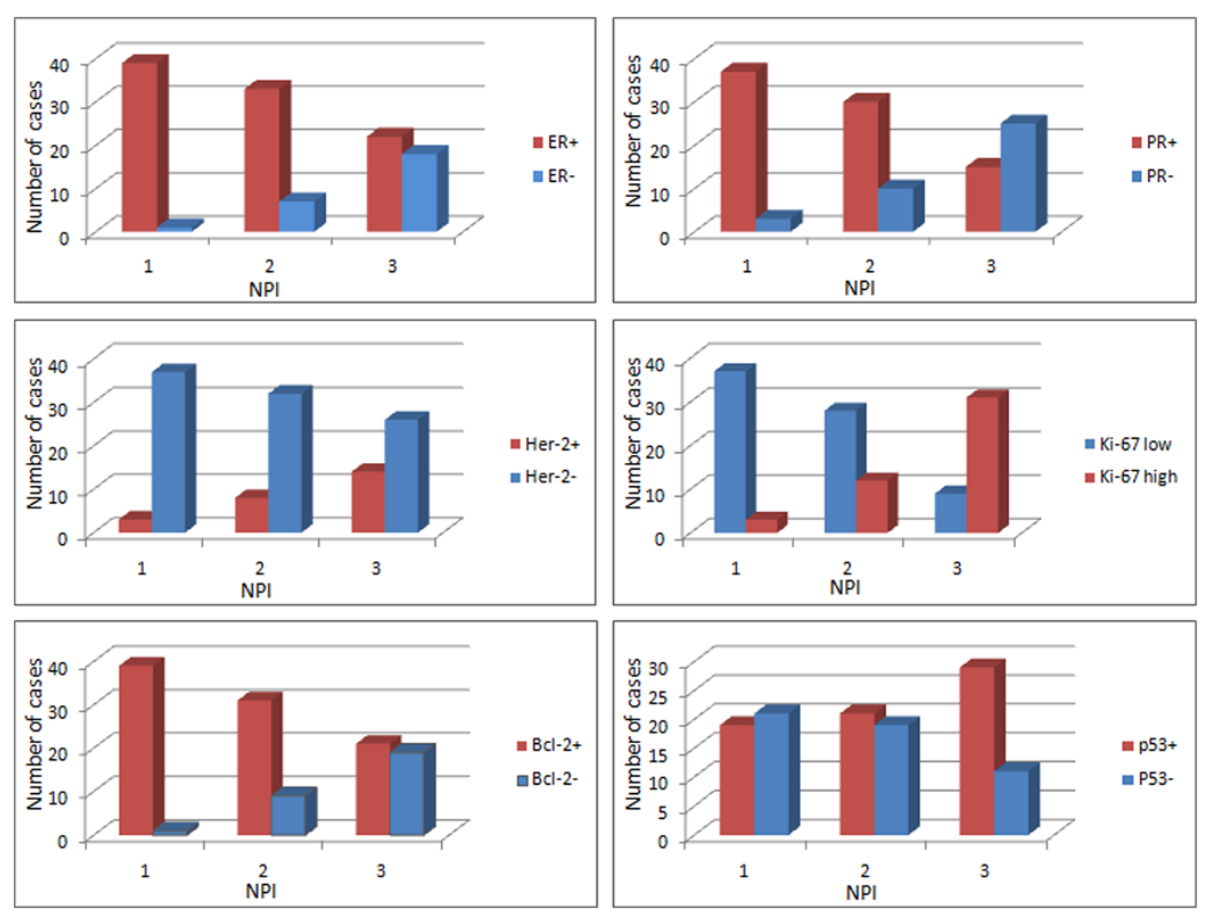

Figure 1 Expression of ER, PR, HER-2/neu, Ki-67, Bcl-2, and p53 in NPI groups.

NPI value, being statistically significant between the groups $(P<0.01$, Figure 1 and Table 3$)$. In contrast, low proliferation index, as measured by Ki-67, was in inverse correlation with NPI value $(P<0.01)$.

As with ER, expression of Bcl-2 was inversely related to NPI numerical value. This difference was statistically significant $(P<0.01)$, reemphasizing its role as a marker of good prognosis. Expression of antioncogenic protein p53 was heterogeneously distributed in the NPI groups without any statistically significant difference $(P=0.057$ Figure 1 and Table 3).

\section{Discussion}

There is ample evidence from clinical, morphological, and molecular genetic studies that breast cancer is a heterogeneous disease [1-4,6-8].

Table 3 Immunohistochemical marker expression in respective NPI groups

\begin{tabular}{|c|c|c|c|c|c|c|c|}
\hline \multirow{2}{*}{ Marker } & \multicolumn{2}{|c|}{ NPI 1} & \multicolumn{2}{|c|}{ NPI 2} & \multicolumn{2}{|c|}{ NPI 3} & \multirow{2}{*}{$\begin{array}{c}\text { Pvalue } \\
\text { [Kruskal-Wallis }\end{array}$} \\
\hline & Neg. & Pos. & Neg. & Pos. & Neg. & Pos. & \\
\hline \multirow{2}{*}{ ER } & 1 & 39 & 7 & 33 & 18 & 22 & \multirow{2}{*}{$P<0.01$} \\
\hline & $2.50 \%$ & $97.50 \%$ & $17.50 \%$ & $82.50 \%$ & $45.00 \%$ & $55.00 \%$ & \\
\hline \multirow{2}{*}{ PR } & 3 & 37 & 10 & 30 & 25 & 15 & \multirow{2}{*}{$P<0.01$} \\
\hline & $7.50 \%$ & $92.50 \%$ & $25 \%$ & $75 \%$ & $62.50 \%$ & $37.50 \%$ & \\
\hline \multirow{2}{*}{ HER-2 } & 37 & 3 & 32 & 8 & 26 & 14 & \multirow{2}{*}{$P=0.01$} \\
\hline & $92.50 \%$ & $7.50 \%$ & $80 \%$ & $20 \%$ & $65 \%$ & $35 \%$ & \\
\hline \multirow{2}{*}{ Ki-67 low } & 3 & 37 & 12 & 28 & 31 & 9 & \multirow{2}{*}{$P<0.01$} \\
\hline & $7.50 \%$ & $92.50 \%$ & $30 \%$ & $70 \%$ & $77.50 \%$ & $22.50 \%$ & \\
\hline \multirow{2}{*}{ Ki-67 high } & 37 & 3 & 28 & 12 & 9 & 31 & \multirow{2}{*}{$P<0.01$} \\
\hline & $92.50 \%$ & $7.50 \%$ & $70 \%$ & $30 \%$ & $22.50 \%$ & $77.50 \%$ & \\
\hline \multirow{2}{*}{$\mathrm{BCl}-2$} & 1 & 39 & 9 & 31 & 19 & 21 & \multirow{2}{*}{$P<0.01$} \\
\hline & $2.50 \%$ & $97.50 \%$ & $22.50 \%$ & $77.50 \%$ & $47.50 \%$ & $52.50 \%$ & \\
\hline \multirow{2}{*}{ p53 } & 21 & 19 & 19 & 21 & 11 & 29 & \multirow{2}{*}{$P=0.57$} \\
\hline & $52.50 \%$ & $47.50 \%$ & $47.50 \%$ & $52.50 \%$ & $27.50 \%$ & $72.50 \%$ & \\
\hline
\end{tabular}


The continuous endeavors of breast cancer researchers are the determination of clinical, morphological, molecular, and genetic indicators for accurate prognostic stratification of patients and the determination of individually tailored therapy [1-16].

Many studies have evaluated combinations of different parameters in order to develop a prognostic profile or prognostic index [1-4,6-12,14,15].

It is generally known that prognosis and treatment of patients with breast carcinoma, NST, are dependent on a few established parameters, such as tumor size, histological grade, lymph node stage, expression of estrogen receptor (ER), progesterone receptor (PR), overexpression of human epidermal growth factor receptor 2 HER-2), and proliferation index determined by Ki-67 [1-16].

Current data also support the use of molecular studies for determination of gene expression profile (GEP), but in some situations, integration of clinico-pathological variables with molecular tests, reproducibility, and cost limit their use $[1,2]$.

The Nottingham Prognostic Index Plus (NPI+) evaluates expression of ten protein biomarkers by immunohistochemistry in order to stratify the patients into seven core classes: class 1 (luminal A), class 2 (luminal $N$ ), class 3 (luminal B), class 4 (basal, p53 altered), class 5 (basal, p53 normal), class 6 (HER-2/neu positive, ER positive), and class 7 (HER-2/neu positive, ER negative) [1,2]. These classes are comparable to those identified by GEP $[1,2]$.

The origins of this system date from the study of 1992 [15]. The original NPI employed a three-tiered stratification system distinguishing good, moderate, and poor prognostic groups [15]. This system has been validated through long periods of clinical follow-up and large multinational and multiinstitutional studies [8-14].

Immunohistochemical determination of ER, PR, HER-2/neu, and Ki-67 is part of the basic histopathological procedures of breast cancer diagnosis in most institutions.

Expression of hormone receptors generally entails favorable prognosis and is an indication for hormonal therapy. In contrast, HER-2/neu overexpression is a marker of adverse prognosis and an indication for trastuzumab therapy.

In line with this general knowledge, we observed that expression of ER and PR was more frequent in NPI groups with favorable prognosis. This expression declined significantly with increasing numerical value. HER-2/neu overexpression was in direct correlation with NPI value. As with ER and PR expression, the frequency of HER-2/neu overexpression was statistically different between the three NPI groups.

Proliferation index, as measured by $\mathrm{Ki}-67$, is a proven prognostic marker [20]. In our study, low and highKi-67 indices were in statistical correlation with low and highNPI numerical value. Some studies have reported on the value of $\mathrm{Bcl}-2$ expression as a good prognostic indicator in breast carcinoma [21,23]. The gene of this protein is activated subsequently to the activation of the estrogen receptor gene, and thus is an indication of ER presence [23]. In our study we observed a strong correlation between ER and Bcl-2 expression, and hence an inverse statistical correlation between $\mathrm{Bcl}-2$ and NPI value.

This is also supported in the study by Zhang et al. [24], who concluded the following: 1) expression of Bcl-2 is associated with better response to hormonal therapy, and 2) expression of $\mathrm{Bcl}-2$ is a good prognostic marker irrespective of the nodal status.

Some early studies have reported an inverse correlation between expression of $\mathrm{Bcl}-2$ and immunohistochemical detection of EGFR, HER-2/neu, and p53 [25,26]. Alsabeh et al. [27] observed that Bcl-2 expression is more common in breast carcinomas with low MIB count.

In our study, expression of antioncogenic protein p53 was heterogeneously distributed in NPI groups without any statistical correlation. Also, expression of this protein was not in correlation with expression of other markers.

There is sufficient evidence to support the role of p53 in breast carcinogenesis despite observations that mutations of this gene are found at lower frequency compared to those in other solid tumors [28]. Studies related to $\mathrm{p} 53$ protein regulation have described new transcription products of p53, highlighting alternative molecular mechanisms, besides mutations, through which p53 is deactivated in breast cancer [28]. The molecular analysis of different stages of p53 protein activity may have diagnostic, prognostic, and therapeutic implications in the future [28].

In early stages of the study, we used a four-to-sixtiered NPI stratification. Even though frequency of expression of prognostic markers was in correlation with NPI value, the statistical significance between the groups could not be reached with respective cut-off values. Hence, the original, three-tiered NPI stratification with cut-off points between values $\leq 3.4,3.45 .4$, and $>5.4$ [15] was more appropriate in statistical terms.

\section{Conclusion}

In conclusion, our study demonstrates that expression of $\mathrm{ER}, \mathrm{PR}$, and $\mathrm{Bcl}-2$ is seen with higher frequency in good and moderate NPI groups. In contrast, overexpression of HER-2/neu is more frequent in moderate and poor NPI groups. The Ki-67 proliferation index is in direct correlation with NPI value.

These data confirm that the original, three-tiered Nottingham Prognostic Index statistically correlates with expression of prognostic immunohistochemical markers in breast carcinoma, NST. 


\section{Consent}

Written informed consent was obtained from the patients for the publication of this report and any accompanying images.

\section{Competing interests}

The authors declare that they have no competing interests.

\section{Authors' contribution}

FK designed the study and wrote the manuscript. LGL contributed in writing the manuscript. SHK analyzed data and contributed in writing the manuscript. MA analyzed data. UG carried out statistical analysis and provided important contribution in data interpretation and study design. All authors read and approved the final manuscript.

\section{Author details}

${ }^{1}$ Institute of Anatomic Pathology, University Clinical Center, Medical School, University of Pristina, Pristina, Kosovo. 'Laboratori Diagnostik Morfopatologjik, Tirana, Albania. ${ }^{3}$ Shërbimi i AnatomisëPatologjike, Qendra Spitalore Universitare NënaTerezë, Tirana, Albania. ${ }^{4}$ American Hospital Kosova, Pristina, Kosovo.

Received: 23 December 2013 Accepted: 20 July 2014

Published: 1 August 2014

\section{References}

1. Rakha EA, Soria D, Green AR, Lemetre C, Powe DG, Nolan CC, Garibaldi JM, Ball G, Ellis IO: Nottingham Prognostic Index Plus (NPI+): a modern clinical decision making tool in breast cancer. Br J Cancer 2014, 110:1688-1697.

2. Green AR, Powe DG, Rakha EA, Soria D, Lemetre C, Nolan CC, Barros FF, Macmillan RD, Garibaldi JM, Ball GR, Ellis IO: Identification of key clinical phenotypes of breast cancer using a reduced panel of protein biomarkers. Br J Cancer 2013, 109:1886-1894.

3. Soria D, Garibaldi JM, Ambrogi F, Green AR, Powe D, Rakha E, Macmillan RD, Blamey RW, Ball G, Lisboa PJ, Etchells TA, Boracchi P, Biganzoli E, Ellis IO: A methodology to identify consensus classes from clustering algorithms applied to immunohistochemical data from breast cancer patients. Comput Biol Med 2010, 40:318-330.

4. Rakha EA, Reis-Filho JS, Baehner F, Dabbs DJ, Decker T, Eusebi V, Fox SB, Ichihara S, Jacquemier J, Lakhani SR, Palacios J, Richardson AL, Schnitt SJ, Schmitt FC, Tan PH, Tse GM, Badve S, Ellis IO: Breast cancer prognostic classification in the molecular era: the role of histological grade. Breast Cancer Res 2010, 12:207.

5. Sundquist M, Thorstenson S, Brudin L, Nordenskjöld B: Applying the Nottingham Prognostic Index to a Swedish breast cancer population. South East Swedish Breast Cancer Study Group. Breast Cancer Res Treat 1999, 53:1-8.

6. Perou CM, Sørlie T, Eisen MB, van de Rijn M, Jeffrey SS, Rees CA, Pollack JR, Ross DT, Ross DT, Johnsen H, Akslen LA, Fluge O, Pergamenschikov A, Williams C, Zhu SX, Lønning PE, Børresen-Dale AL, Brown PO, Botstein D: Molecular portraits of human breast tumours. Nature 2000, 406:747-752.

7. Sørlie T, Perou CM, Tibshirani R, Aas T, Geisler S, Johnsen H, Hastie T, Eisen MB, van de Rijn M, Jeffrey SS, Thorsen T, Quist H, Matese JC, Brown PO, Botstein D, Lønning PE, Børresen-Dale AL: Gene expression patterns of breast carcinomas distinguish tumor subclasses with clinical implications. Proc Natl Acad Sci U S A 2001, 98:10869-10874.

8. Sotiriou C, Neo SY, McShane LM, Korn EL, Long PM, Jazaeri A, Martiat P, Fox SB, Harris AL, Liu ET: Breast cancer classification and prognosis based on gene expression profiles from a population-based study. Proc Natl Acad Sci U S A 2003, 100:10393-10398.

9. Chen C, Dhanda R, Tseng W-Y, Forsyth M, Patt DA: Evaluating use characteristics for the oncotype $\mathrm{dx}$ 21-gene recurrence score and concordance with chemotherapy use in early-stage breast cancer. J Oncol Pract Am Soc Clin Oncol 2013, 9:182-187.

10. De Boer RH, Baker C, Speakman D, Chao CY, Yoshizawa C, Mann GB: The impact of a genomic assay (Oncotype DX) on adjuvant treatment recommendations in early breast cancer. Med J Aust 2013, 199:205-208.
11. Carlson JJ, Roth JA: The impact of the OncotypeDx breast cancer assay in clinical practice: a systematic review and meta-analysis. Breast Cancer Res Treat 2013, 141:13-22.

12. Geradts J, Bean SM, Bentley RC, Barry WT: The oncotype DX recurrence score is correlated with a composite index including routinely reported pathobiologic features. Cancer Invest 2010, 28:969-977.

13. DeFrank JT, Salz T, Reeder-Hayes K, Brewer NT: Who gets genomic testing for breast cancer recurrence risk? Public Health Genomics 2013, 16:215-222.

14. Harbeck N, Sotlar K, Wuerstlein R, Doisneau-Sixou S: Molecular and protein markers for clinical decision making in breast cancer: today and tomorrow. Cancer Treat Rev 2014, 40:434-444.

15. Galea MH, Blamey RW, Elston CE, Ellis IO: The Nottingham Prognostic Index in primary breast cancer. Breast Cancer Res Treat 1992, 22:207-219.

16. Rakha EA, El-Sayed ME, Lee AHS, Elston CW, Grainge MJ, Hodi Z, Blamey RW, Ellis IO: Prognostic significance of Nottingham histologic grade in invasive breast carcinoma. J Clin Oncol 2008, 26:3153-3158.

17. Blamey RW, Ellis IO, Pinder SE, Lee AHS, Macmillan RD, Morgan DA, Robertson JF, Mitchell MJ, Ball GR, Haybittle JL, Elston CW: Survival of invasive breast cancer according to the Nottingham Prognostic Index in cases diagnosed in 19901999. Eur J Cancer 2007, 43:1548-1555.

18. Hammond MEH, Hayes DF, Dowsett M, Allred DC, Hagerty KL, Badve S, Fitzgibbons PL, Francis G, Goldstein NS, Hayes M, Hicks DG, Lester S, Love R, Mangu PB, McShane L, Miller K, Osborne CK, Paik S, Perlmutter J, Rhodes A, Sasano H, Schwartz JN, Sweep FC, Taube S, Torlakovic EE, Valenstein P, Viale G, Visscher D, Wheeler T, Williams RB, et al: American Society of Clinical Oncology/College of American Pathologists Guideline Recommendations for Immunohistochemical Testing of Estrogen and Progesterone Receptors in Breast Cancer. Arch Pathol Lab Med 2010, 134:907-922.

19. Wolff AC, Hammond ME, Hicks DG, Dowsett M, McShane LM, Allison KH, Allred DC, Bartlett JM, Bilous M, Fitzgibbons P, Hanna W, Jenkins RB, Mangu PB, Paik S, Perez EA, Press MF, Spears PA, Vance GH, Viale G, Hayes DF: Recommendations for Human Epidermal Growth Factor Receptor 2 Testing in Breast Cancer: American Society of Clinical Oncology/College of American Pathologists Clinical Practice Guideline Update. J Clin Oncol 2013, 31:3997-4013

20. Goldhirsch A, Winer EP, Coates AS, Gelber RD, Piccart-Gebhart M, Thürlimann B, Senn HJ: Personalizing the treatment of women with early breast cancer: highlights of the St Gallen International Expert Consensus on the Primary Therapy of Early Breast Cancer 2013. Ann Oncol 2013, 24:2206-2223.

21. Callagy GM, Pharoah PD, Pinder SE, Hsu FD, Nielsen TO, Ragaz J, Ellis IO, Huntsman D, Caldas C: Bcl-2 is a prognostic marker in breast cancer independently of the Nottingham Prognostic Index. Clin Cancer Res 2006, 12:2468-2475

22. Yamashita $H$, Toyama $T$, Nishio $M$, Ando $Y$, Hamaguchi M, Zhang Z, Kobayashi S, Fujii Y, Iwase $\mathrm{H}$ : p53 protein accumulation predicts resistance to endocrine therapy and decreased post-relapse survival in metastatic breast cancer. Breast Cancer Res 2006, 8:R48

23. Hwang KT, Woo JW, Shin HC, Kim HS, Ahn SK, Moon HG, Han W, Park IA, Noh DY: Prognostic influence of BCL2 expression in breast cancer. Int J Cancer 2012, 131:1109-1119.

24. Zhang GJ, Kimijima I, Tsuchiya A, Abe R: The role of bcl-2 expression in breast carcinomas (Review). Oncol Rep 1998, 5:1211-1216.

25. Miyashita T, Krajewski S, Krajewska M, Wang HG, Lin HK, Liebermann DA, Hoffman B, Reed JC: Tumor suppressor p53 is a regulator of bcl-2 and bax gene expression in vitro and in vivo. Oncogene 1994, 9:1799-1805.

26. Haldar S, Negrini M, Monne M, Sabbioni S, Croce CM: Down-regulation of bcl-2 by p53 in breast cancer cells. Cancer Res 1994, 54:2095-2097.

27. Alsabeh R, Wilson CS, Ahn CW, Vasef MA, Battifora H: Expression of bcl-2 by breast cancer: a possible diagnostic application. Mod Pathol 1995, 9:439-444.

28. Vogelstein B, Kinzler KW: Achilles' heel of cancer? Nature 2001, 412:865-866.

\section{doi:10.1186/1477-7819-12-243}

Cite this article as: Kurshumliu et al:: Classification of patients with breast cancer according to Nottingham Prognostic Index highlights significant differences in immunohistochemical marker expression. World Journal of Surgical Oncology 2014 12:243. 